\title{
Intertidal barnacles as indicators of the intensity of scour by sea ice
}

\author{
Kiva M. Belt, Stephen W. B. Cole, Ricardo A. Scrosati* \\ Department of Biology, Saint Francis Xavier University, Antigonish, Nova Scotia B2G 2W5, Canada
}

\begin{abstract}
We investigated the potential utility of intertidal barnacles as ecological indicators of the intensity of ice scour on the Gulf of St. Lawrence coast of Nova Scotia, Canada. This coast is extensively covered by sea ice in winter. Shortly after ice melt, between May and June 2007, we quantified the density of adult barnacles Semibalanus balanoides in the high intertidal zone in 8 rocky locations distributed along nearly $25 \mathrm{~km}$ of coastline. At each location, we took measurements in 2 types of habitat that differ in ice scour intensity: habitats facing open waters, where ice scour is intense, and habitats facing a rocky land mass between a few meters and 10s of meters away, where ice scour is moderate. Adult barnacle density was significantly higher in sheltered sites than in exposed sites by a factor of 3 , on average. Ice scour intensity is likely the main factor determining such a pattern, as we previously found that barnacle recruitment is similar in both types of habitat and that the potential competitors (algae and mussels) and predators (whelks) are virtually absent in the high intertidal zone. Thus, high-intertidal barnacles might serve as indicators of differences in ice scour intensity among coastal sites in our region. Future studies should determine the spatial scales of applicability of this approach.
\end{abstract}

KEY WORDS: Barnacle $\cdot$ Ecological indicator $\cdot$ Ice scour $\cdot$ Intertidal zone $\cdot$ Sea ice Resale or republication not permitted without written consent of the publisher

\section{INTRODUCTION}

On polar and subpolar marine shores, sea ice is an important factor affecting the ecology of benthic organisms and a number of human activities (Barnes 1999, Gutt 2001, Leppäranta 2005). In recent years, studies on the ecological impact of sea ice on highlatitude shores have intensified (Barnes \& Conlan 2007). Central to these studies is the quantification of the intensity of scour caused by sea ice on the substrate when the ice moves because of currents, wind, waves, or tides. For example, the damage that icebergs cause on the coastal sea floor can be measured by determining the physical condition of concrete markers that are secured to the substrate for variable periods of time (Brown et al. 2004, Smale et al. 2007). In rocky intertidal habitats that receive a lower degree of ice load, metallic cages can indicate the cumulative damage caused by ice through the measurement of morphological changes in the cages (Scrosati \& Heaven 2006).
Like all field methods, those to assess damage by ice on marine shores have virtues and limitations. The clearest advantage of such methods is their ability to measure ice scour for the exact sites of interest at the desired level of spatial resolution. This is important to recognize because several international agencies report sea ice conditions regularly (World Meteorological Organization 2006), but they generally do it at a coarser spatial resolution than that needed to understand ecological phenomena that vary at local scales. Some studies have estimated ice scour intensity based on the cover of sea ice in coastal waters and on the number of days during which floating ice was visible from the coast (Keats et al. 1985), but that method also provides estimates at a coarse spatial resolution and is only valid for shore areas that are directly exposed to the incoming ice fragments. The usefulness of in situ measurements thus becomes clear. Among the limitations of direct-measurement methods, perhaps the most obvious one is of a practical nature. Problems of 
time, funding, and/or field assistance may preclude the deployment and subsequent monitoring of enough field sensors to cover the desired spatial extent and resolution.

Ecological indicators are organisms that provide information on the environment that would be difficult or impossible to obtain by direct abiotic measurements because of practical limitations (Niemi \& McDonald 2004, Borja \& Dauer 2008). To determine the levels of coastal ice scour at large spatial extents or high spatial resolutions, it would thus be ideal to identify ecological indicators to generate data quickly and inexpensively (Salas et al. 2006). In eastern Canada, many shores experience a significant development of sea ice every winter. In rocky intertidal habitats that suffer intense ice scour in winter, adult barnacles occur almost exclusively in cracks and crevices because such places constitute refuges against the physical abrasion caused by the ice (Bergeron \& Bourget 1986). A study done at 1 location in northern Nova Scotia suggests that the density of adult barnacles in spring might be inversely related to the intensity of winter ice scour, as many individuals survive outside of crevices in habitats where ice scour is moderate (MacPherson et al. 2008). However, the lack of location replication in that study precludes the establishment of any generalizations. To test whether intertidal barnacles might be useful indicators of the intensity of winter ice scour, we conducted a large-scale mensurative study that surveyed several locations at a regional scale. Our hypothesis was that adult barnacles would be more abundant in habitats subjected to moderate levels of ice scour than in habitats in which ice scour is strong.

\section{MATERIALS AND METHODS}

We studied 8 rocky intertidal locations distributed along nearly $25 \mathrm{~km}$ on the Gulf of St. Lawrence coast of Nova Scotia, between Arisaig Point $\left(45^{\circ} 45.80^{\prime} \mathrm{N}\right.$, $\left.62^{\circ} 10.28^{\prime} \mathrm{W}\right)$ and an unnamed place $\left(45^{\circ} 53.20^{\prime} \mathrm{N}\right.$, $61^{\circ} 55.51^{\prime} \mathrm{W}$ ) near Cape George Point (Fig. 1). The topography of the rocky sections of this coast is often complex at a local scale. Each of our study locations included an exposed site, which faced open waters directly, and a sheltered site, which was protected from incoming swell by outer rocky formations or by being on the shoreward side of rocky outcrops. Exposed sites are subjected to a higher degree of wave action than sheltered sites. In situ measurements done on this coast using dynamometers (Carrington Bell \& Denny 1994) indicated that maximum wave velocity averaged $5.2 \mathrm{~m} \mathrm{~s}^{-1}$ in exposed sites and $3.4 \mathrm{~m} \mathrm{~s}^{-1}$ in sheltered sites over several $24 \mathrm{~h}$ periods surveyed in the summer and autumn of 2005 (Scrosati \& Heaven

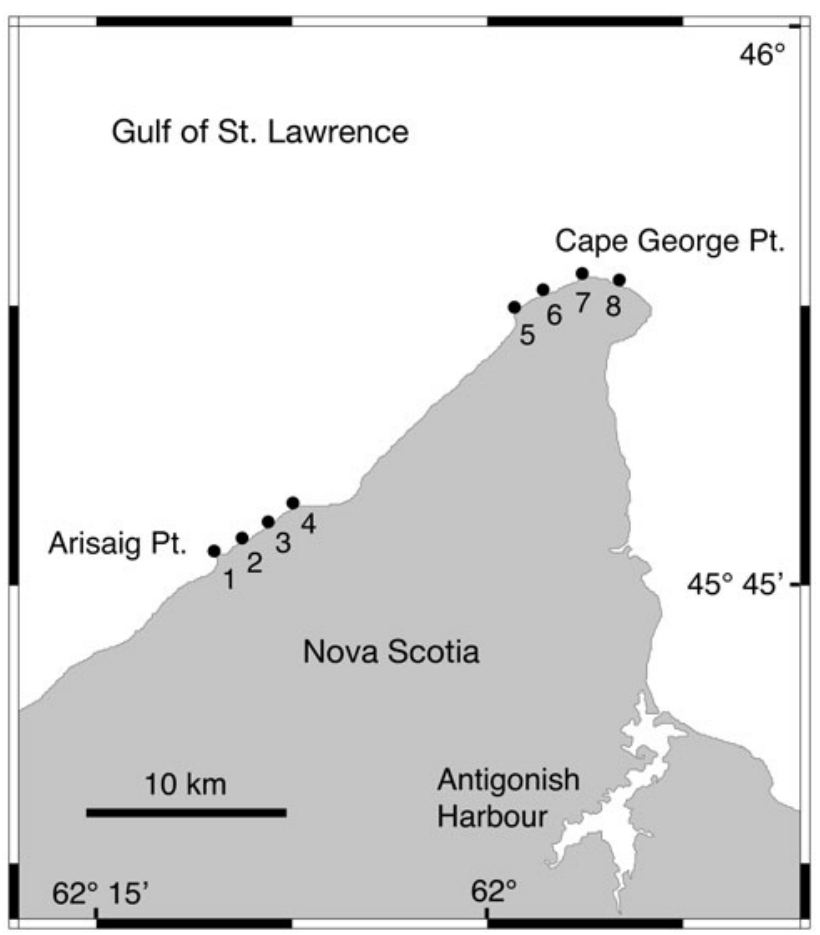

Fig. 1. Northern shore of Nova Scotia (Canada), showing the position of the 8 study locations along the Gulf of St. Lawrence coast. Locations were only established on coastal ranges depicting stable bedrock because barnacles are abundant there. The other coastal ranges on the map mostly depict boulder fields or cobble/pebble beaches, which represent unstable substrate for benthic species in general

2007). Sea ice forms in early winter and melts between late winter and early spring in this region (Saucier et al. 2003, Scrosati \& Eckersley 2007). At the peak of the winter, sea ice is well developed and covers the entire shore. For the 2004/2005 winter, in situ measurements of the damage (angle of deformation) caused by sea ice to metallic cages affixed to the rocky substrate indicated that ice scour is significantly stronger on exposed sites (mean deformation angle of $90^{\circ}$ ) than on sheltered sites (mean deformation angle of $47^{\circ}$; Scrosati \& Heaven 2006). For this reason, in the present article the term 'exposed' will refer hereafter to high levels of wave action and ice scour, whereas the term 'sheltered' will refer to low levels of those variables. Pictures showing the positive spatial relationship between the degree of wave exposure and the intensity of ice scour in a typical location have been published in Scrosati \& Heaven (2007).

At each of our studied locations, and separately for exposed and sheltered sites, we determined the density of adult barnacles Semibalanus balanoides in the high intertidal zone between 6 May and 5 June 2007. This is a good candidate species as an ecological indi- 
cator because it is common on NW Atlantic rocky shores (Drouin et al. 2002), often being the only intertidal barnacle in the Gulf of St. Lawrence (Véliz et al. 2004, Scrosati \& Heaven 2007). We considered the high intertidal zone to be the upper third of the full intertidal range, which is $1.8 \mathrm{~m}$ on the surveyed coast. We only sampled large areas consisting of stable bedrock, avoiding unstable substrate such as boulder fields or cobble/pebble beaches. We defined adult barnacles as individuals that had survived the previous winter. No information exists on barnacle age for this coast, but it is easy in the spring to identify overwintering individuals and those that were recruited after ice melt. Recruitment in $S$. balanoides populations occurs during the spring in Atlantic Canada (Bousfield 1954, Minchinton \& Scheibling 1991). On the Gulf of St. Lawrence coast of Nova Scotia, recruits are abundant both inside and outside of cracks and crevices in spring, reaching sitewise averages of 300 to 400 recruits $\mathrm{dm}^{-2}$ in the high intertidal zone (MacPherson \& Scrosati 2008). Recruits are, however, considerably smaller than adults at that time (Fig. 2), thus making the determination of adult barnacle density a straightforward process. We counted the number of adult barnacles in 20 quadrats $(25 \mathrm{~cm} \times 25 \mathrm{~cm})$ that were randomly located along a transect line at an exposed site and a sheltered site, at each of our 8 locations (40 quadrats in total per location). Exposed sites faced open waters directly, whereas sheltered sites faced a land mass (rocky formations) between a few meters and 10s of meters away. The stretch of shoreline surveyed at each location was 90 to $100 \mathrm{~m}$.

We analyzed the data on adult barnacle density through a nested ANOVA (Quinn \& Keough 2002). We considered exposure as a fixed factor (with 2 levels: exposed and sheltered) and site as a random factor (with 8 levels) nested within exposure. Since testing the effect of exposure had to be based on the site means, given that the site factor was random, the normality and homoscedasticity assumptions for the exposure test applied to those means (Quinn \& Keough 2002). Thus, we assessed the normality assumption by using the site means to produce a normal probability plot for each exposure level, which allowed us to accept this assumption. We accepted the homoscedasticity assumption based on a Levene's test $\left(F_{1,14}=\right.$ $0.012, \mathrm{p}=0.916$ ). We performed the analyses using SYSTAT 5.2 for Macintosh (Wilkinson et al. 1992).

\section{RESULTS AND DISCUSSION}

Adult barnacles Semibalanus balanoides were present at all of the sites that we surveyed in the high intertidal zone along the Gulf of St. Lawrence coast of Nova Scotia between May and June 2007. The nested ANOVA, however, indicated that the density of adult barnacles was significantly higher in sheltered sites $\left(21.5 \pm 1.2\right.$ individuals $\mathrm{dm}^{-2}$, mean $\left.\pm \mathrm{SE}, \mathrm{n}=8\right)$ than in exposed sites $\left(6.9 \pm 2.1\right.$ individuals $\left.\mathrm{dm}^{-2}\right)$ of the shore

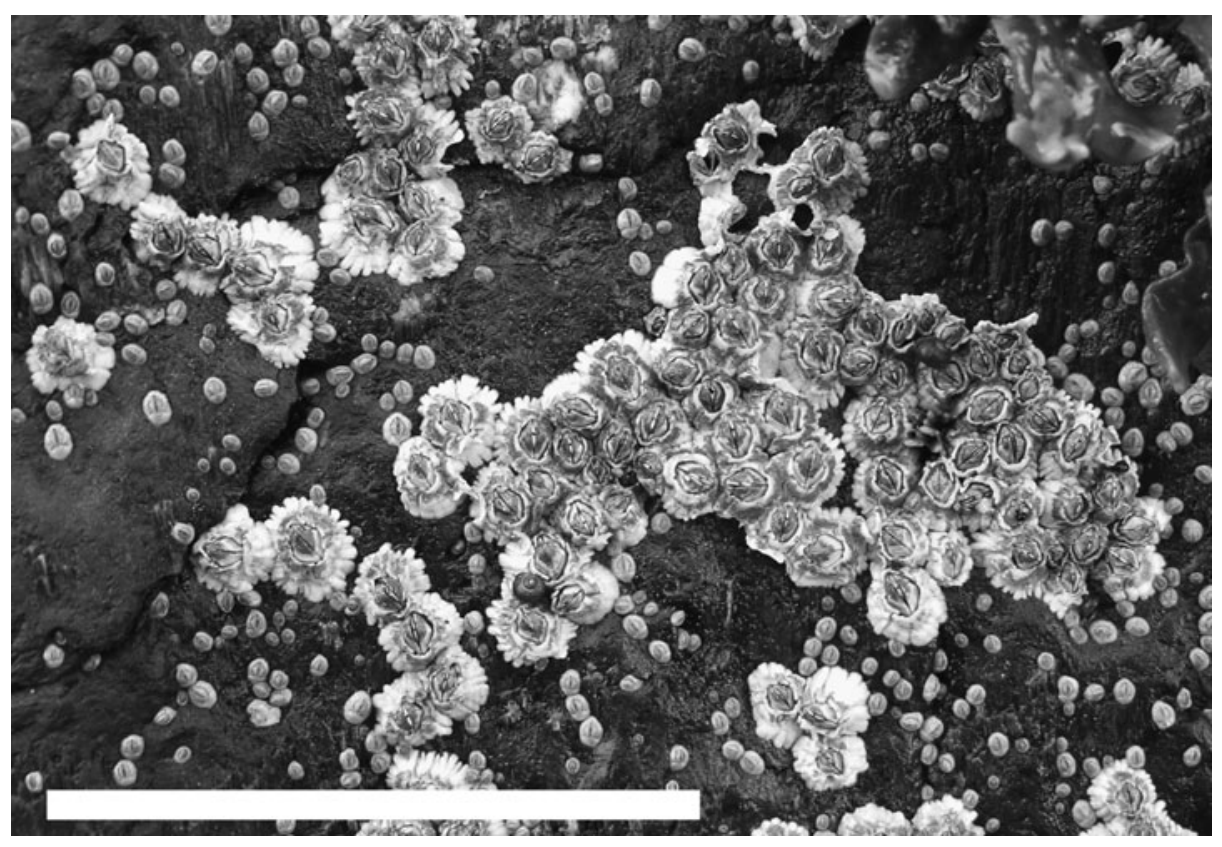

Fig. 2. Semibalanus balanoides. Barnacles in the high intertidal zone as seen in the spring on the Gulf of St. Lawrence coast of Nova Scotia, showing the large difference in size between adults and recruits. Scale bar $=5 \mathrm{~cm}$. Photo by R. A. Scrosati 
Table 1. Summary table for the nested ANOVA performed to test for the effects of exposure and site within exposure (see 'Results and discussion' for definitions) on the density of adult barnacles in the high intertidal zone in spring in northern Nova Scotia

\begin{tabular}{|c|c|c|c|c|c|}
\hline $\begin{array}{l}\text { Source of } \\
\text { variation }\end{array}$ & $\mathrm{df}$ & SS & MS & $F$ & $\mathrm{p}$ \\
\hline Exposure & 1 & 17085.52 & 17085.52 & 34.88 & 0.00004 \\
\hline Site (Exposure) & 14 & 6856.78 & 489.77 & 2.88 & 0.00042 \\
\hline Error & 304 & 51677.26 & 169.99 & & \\
\hline Total & 319 & 75619.56 & & & \\
\hline
\end{tabular}

(Table 1). Differences in adult barnacle density existed among sites (Table 1), but adult barnacles were consistently more abundant in sheltered sites than in exposed sites across the 8 locations that we studied (Fig. 3). Therefore, we found field evidence that supports our hypothesis.

Our study thus backs the notion that spring adult barnacle density could be used as an index of the relative intensity of winter ice scour at local spatial scales. This concept is to be strengthened by determining whether ice scour intensity is, in fact, the major factor affecting barnacle abundance in the high intertidal zone. No experiment has managed to manipulate ice scour intensity under field conditions on the shore, but there is a diverse body of evidence suggesting that the mechanistic link between ice scour and adult barnacle abundance does exist. First, the supply of new organisms does not explain differences in adult barnacle density between exposed and sheltered habitats. On our studied shore, new individuals of Semibalanus bal-

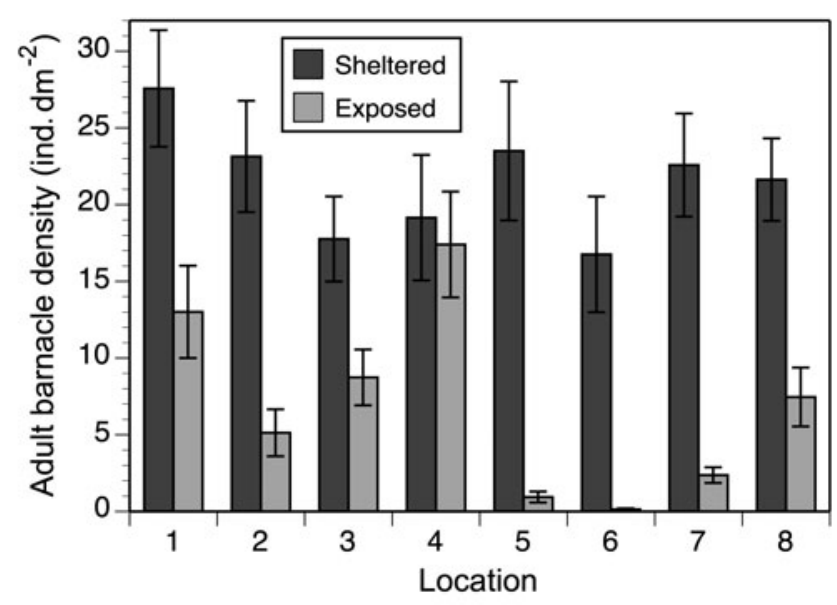

Fig. 3. Semibalanus balanoides. Density of adult barnacles (mean $\pm \mathrm{SE} ; \mathrm{n}=20$ quadrats) in exposed and sheltered sites (see 'Materials and methods' for definitions) in the high intertidal zone at 8 locations along the Gulf of St. Lawrence coast of Nova Scotia in the spring of 2007 anoides are recruited only after ice melt every year, and measurements done in 2 consecutive years indicated that recruit density is similar in sheltered and exposed habitats (MacPherson et al. 2008). Interspecific interactions also do not seem to affect barnacle abundance in the high intertidal zone. On other North Atlantic shores, competitors (fucoid seaweeds and mussels) and predators (whelks) have been shown to affect the abundance of $S$. balanoides (Gosselin \& Bourget 1989, Minchinton \& Scheibling 1993, Jenkins et al. 1999, Leonard 2000). However, those organisms are virtually restricted to mid- and low intertidal elevations on the Gulf of St. Lawrence coast of Nova Scotia (Scrosati \& Heaven 2007). Also, on our studied shore, the rocky substrate becomes widely covered by barnacles every autumn, as the numerous recruits from the preceding spring grow to adult size by autumn (MacPherson \& Scrosati 2008). The entire coast is later covered by ice for the winter, and, thus, ice scour intensity emerges as the main factor likely explaining the differences in adult barnacle density between exposed and sheltered habitats in the high intertidal zone in spring. No other abiotic factors (e.g. wave action, wind) seem to have determined the differences in adult barnacle density between exposed and sheltered sites between ice melt and the time of our measurements. Our studied coast became free of ice only at the end of April (Canadian Ice Service 2008), and we never observed any noticeable change in adult barnacle density at any site during our month-long study shortly after ice melt.

It is also worth noting that restricting density measurements to the high intertidal zone, as opposed to lower elevations at which barnacles also occur (MacPherson \& Scrosati 2008), confers a practical advantage. High elevations are exposed to the air for longer periods of time than lower elevations because of tide dynamics (Raffaelli \& Hawkins 1996), which should allow surveyors to take more field measurements per tidal cycle.

Barnacles might not only serve to infer differences in ice scour intensity among sites, but also interannual differences for the same sites. Such information is particularly necessary for studies of the impact of climate change on high-latitude shores (Smale \& Barnes 2008). Regarding comparisons among sites, we must emphasize that the utility of barnacles as ecological indicators will be limited to spatial scales at which ice scour intensity is known or suspected to be the primary factor affecting barnacle abundance. This was seemingly the case at local spatial scales (between exposed and sheltered habitats) in our study, but, at regional spatial scales, it might not be true. For example, at scales spanning several 100s of kilometers or a few 1000s of kilometers, differences in the abundance of coastal 
phytoplankton (food for barnacles) or in the nature of coastal currents (which may drive larvae offshore) are known to affect barnacle density on the shore (Connolly et al. 2001, Bertness 2007). Under those scenarios, the comparison of adult barnacle density between sites belonging to distant regions might not allow one to infer differences in ice scour intensity reliably between such sites. Therefore, the use of barnacles as ecological indicators of ice scour intensity on different high-latitude shores around the world will need to be preceded by the identification of the spatial scales at which ice scour intensity is the main determinant of adult barnacle density.

Acknowledgements. We are grateful to P. J. Williams and to 4 anonymous reviewers, for their constructive comments on the manuscript, and to M. Chadwick (Fisheries and Oceans Canada, Gulf Region), for financial support to S.W.B.C. through a DFO graduate scholarship. This work represents the B.Sc. Honours thesis of K.M.B. at Saint Francis Xavier University. Research was funded by grants from the Natural Sciences and Engineering Research Council of Canada (NSERC), the Canada Research Chairs program (CRC), and the Canada Foundation for Innovation (CFI) to R.A.S.

\section{LITERATURE CITED}

Barnes DKA (1999) The influence of ice on polar nearshore benthos. J Mar Biol Assoc UK 79:401-407

Barnes DKA, Conlan KE (2007) Disturbance, colonization and development of Antarctic benthic communities. Philos Trans R Soc Lond B 362:11-38

Bergeron P, Bourget E (1986) Shore topography and spatial partitioning of crevice refuges by sessile epibenthos in an ice disturbed environment. Mar Ecol Prog Ser 28:129-145

Bertness MD (2007) Atlantic shorelines. Natural history and ecology. Princeton University Press, Princeton, NJ

> Borja A, Dauer DM (2008) Assessing the environmental quality status in estuarine and coastal systems: comparing methodologies and indices. Ecol Indic 8:331-337

Bousfield EL (1954) The distribution and spawning seasons of barnacles on the Atlantic coast of Canada. Bull Nat Mus Can 132:112-154

Brown KM, Fraser KPP, Barnes DKA, Peck LS (2004) Links between the structure of an Antarctic shallow-water community and ice-scour frequency. Oecologia 141:121-129

Canadian Ice Service (2008) Canadian ice service. Available at: www.ice-glaces.ec.gc.ca (accessed on 24 November)

Carrington Bell E, Denny MW (1994) Quantifying 'wave exposure': a simple device for recording maximum velocity and results of its use at several field sites. J Exp Mar Biol Ecol 181:9-29

Connolly SR, Menge BA, Roughgarden J (2001) A latitudinal gradient in recruitment of intertidal invertebrates in the northeast Pacific Ocean. Ecology 82:1799-1813

> Drouin CA, Bourget E, Tremblay R (2002) Larval transport processes of barnacle larvae in the vicinity of the interface between two genetically different populations of Semibalanus balanoides. Mar Ecol Prog Ser 229:165-172

Gosselin LA, Bourget E (1989) The performance of an intertidal predator, Thais lapillus, in relation to structural heterogeneity. J Anim Ecol 58:287-303

Gutt J (2001) On the direct impact of ice on marine benthic communities, a review. Polar Biol 24:553-564
Jenkins SR, Norton TA, Hawkins SJ (1999) Settlement and post-settlement interactions between Semibalanus balanoides (L.) (Crustacea: Cirripedia) and three species of fucoid canopy algae. J Exp Mar Biol Ecol 236:49-67

Keats DW, South GR, Steele DH (1985) Algal biomass and diversity in the upper subtidal at a pack-ice disturbed site in eastern Newfoundland. Mar Ecol Prog Ser 25:151-158

Leonard GH (2000) Latitudinal variation in species interactions: a test in the New England rocky intertidal zone. Ecology 81:1015-1030

Leppäranta M (2005) The drift of sea ice. Springer, Berlin

> MacPherson EA, Scrosati R (2008) Population structure of the barnacle, Semibalanus balanoides (Cirripedia, Thoracica), across intertidal environmental stress gradients in northern Nova Scotia, Canada. Crustaceana 81:725-736

> MacPherson EA, Scrosati R, Chareka P (2008) Barnacle recruitment on ice-scoured shores in eastern Canada. J Mar Biol Assoc UK 88:289-291

Minchinton TE, Scheibling RE (1991) The influence of larval supply and settlement on the population structure of barnacles. Ecology 72:1867-1869

> Minchinton TE, Scheibling RE (1993) Free-space availability and larval substratum selection as determinants of barnacle population structure in a developing rocky intertidal community. Mar Ecol Prog Ser 95:233-244

Niemi GJ, McDonald ME (2004) Application of ecological indicators. Annu Rev Ecol Evol Syst 35:89-111

Quinn GP, Keough MJ (2002) Experimental design and data analysis for biologists. Cambridge University Press, Cambridge

Raffaelli D, Hawkins S (1996) Intertidal ecology. Chapman \& Hall, London

Salas F, Marcos C, Neto JM, Patrício J, Pérez-Ruzafa A, Marques JC (2006) User-friendly guide for using benthic ecological indicators in coastal and marine quality assessment. Ocean Coast Manag 49:308-331

Saucier FJ, Roy F, Gilbert D, Pellerin P, Ritchie H (2003) Modeling the formation and circulation processes of water masses and sea ice in the Gulf of St. Lawrence, Canada. J Geophys Res 108(C8), 3269, doi:10.1029/2000JC000686

Scrosati R, Eckersley LK (2007) Thermal insulation of the intertidal zone by the ice foot. J Sea Res 58:331-334

> Scrosati R, Heaven C (2006) Field technique to quantify scouring by sea ice in rocky intertidal communities. Mar Ecol Prog Ser 320:293-295

- Scrosati R, Heaven C (2007) Spatial trends in community richness, diversity, and evenness across rocky intertidal environmental stress gradients in eastern Canada. Mar Ecol Prog Ser 342:1-14

Smale DA, Barnes DKA (2008) Likely responses of the Antarctic benthos to climate-related changes in physical disturbance during the 21st century, based primarily on evidence from the West Antarctic Peninsula region. Ecography 31:289-305

- Smale DA, Barnes DKA, Fraser KPP (2007) The influence of depth, site exposure, and season on the intensity of iceberg scouring in nearshore Antarctic waters. Polar Biol 30: 769-779

Véliz D, Bourget E, Bernatchez L (2004) Regional variation in the spatial scale of selection at MPI and GPI in the acorn barnacle Semibalanus balanoides (Crustacea). J Evol Biol 17:953-966

Wilkinson L, Hill MA, Vang E (1992) SYSTAT: statistics, Version 5.2. SYSTAT, Evanston, IL

World Meteorological Organization (2006) Sea-ice information services in the world. Document No. 574, World Meteorological Organization, Geneva

Submitted: September 10, 2008; Accepted: January 19, 2009

Proofs received from author(s): March 25, 2009 